\title{
GEORG KNOFF'S COLLECTION IN GDAŃSK REMARKS ON COLLECTING AND DISSEMINATING PRINTED MUSIC
}

\author{
PAWEŁ GANCARCZYK \\ Polska Akademia Nauk, Warszawa
}

Izvleček: Georg Knoff, patricij iz mesta Gdansk, je proti koncu 16. stoletja ustvaril zbirko 267 glasbenih tiskov večinoma beneškega izvora. Avtor te razprave predvideva, da je Knoff glasbene tiske pridobival po poti neposrednih stikov z Benetkami. Zbirka očitno ni bila namenjena izvajanju glasbe, temveč bolj izrazu Knoffovega družbenega položaja.

Ključne besede: glasbeno tiskarstvo, zbirke, 16. stoletje, Gdansk, Benetke, Georg Knoff.

\begin{abstract}
Georg Knoff, a patrician from Gdańsk, amassed towards the end of the sixteenth century a collection of 267 music prints, the majority of them originating from Venice. The author puts forward the hypothesis that Knoff obtained the editions by making use of direct contacts with Italy. The aim of the collection was not so much to provide repertory for performance as to emphasize Knoff's social status.
\end{abstract}

Keywords: music printing, collections, sixteenth century, Gdańsk, Venice, Georg Knoff.

The development of printing meant that the sixteenth century witnessed the arrival on the market of a significant number of music publications that could be obtained relatively easily at a reasonable price. This aided the creation of music collections not only by court or church ensembles but also by members of the middle class. ${ }^{1}$ As early as the beginning of the sixteenth century Ferdinand Columbus, during his travels in Europe, purchased a variety of prints, which included editions from such printing firms as Petrucci, Antico, Attaingnant and Moderne. ${ }^{2}$ His collection - numbering 172 music editions - was merely a harbinger of a phenomenon that reached its peak during the last decades of the sixteenth century. German patricians such as Hans Jakob Fugger, Johann Georg von Werdenstein and Hans Heinrich Herwart each collected a few hundred music prints from printing houses throughout the whole of Europe. Against this background the collection of the Gdańsk patrician Georg Knoff(d. 1605), numbering 267 prints from the period 1568-1601, appears particularly interesting. What makes it unusual is the fact that Italian editions

1 See Bernstein, "Buyers and Collectors," 21-34.

2 Chapman, "Printed Collections of Polyphonic Music," 34-84. 
represent an exceptionally large portion of the collection, and the majority of these prints contain madrigalian repertory.

In 1615 Knoff's collection passed to the library of the Municipal Senate of Gdańsk, and a significant part of it has been preserved up to the present day at the Gdańsk Library of the Polish Academy of Sciences (Polska Akademia Nauk, Biblioteka Gdańska). ${ }^{3}$ It attracted the attention of Karl-Günther Hartmann, ${ }^{4}$ whose work was followed by a detailed study by Martin Morell. ${ }^{5}$ Numerous scholars researching the history of music in the second half of the sixteenth century refer to the contents of the collection - which include over a dozen prints that have not survived anywhere else. Despite this, the collection continues to raise many questions. In particular, we have no clear understanding of the reasons why Knoff should have collected such a large number of prints, the majority of which contain works that might appear to be alien and incomprehensible in Royal Prussia. Another question relates to the routes by which Italian music prints found their way to Gdańsk, a city that culturally and geographically was much closer to printing centres located in the Netherlands or in Germany. In this article I attempt to answer these questions, taking Knoff's collection as a "case study" illustrating some aspects of collection building and the distribution of music prints in the sixteenth century.

As already mentioned, Georg Knoff's collection comprises 267 music prints. ${ }^{6}$ Most of them are bound into larger sets of multiple partbooks combined under a common call number. Among the twenty-six original sets four are regarded as lost. In the majority of cases a single call number refers to ten to twelve separate publications. Two sets are anomalous in this respect: Ee $2173^{2}$ includes four editions, while Ee1856 contains only one edition: the Newe Lieder of Johannes Eccard (Königsberg: Georg Osterberger, 1589). As many as 219 editions ( $82 \%$ of the collection) come from Italian printers, the majority featuring secular repertory: alongside "serious" madrigals for five or six voices we find lighter forms (madrigaletti, canzonette, canzoni alla napolitana). Characteristically, with only a few exceptions, these are Venetian prints, primarily from the printing shop of Angelo Gardano (143 items), and to a lesser extent from Scotto (thirty-eight items) as well as Ricciardo Amadino and Giacomo Vincenti (thirty-two items). German prints constitute as little as thirteen per cent, and Flemish ones four per cent, of the collection. There are three Prussian prints, but French, Czech and English editions are totally absent. We are thus dealing with a collection having a clearly Italian orientation, and this to a degree not normally encountered north of the Alps. To cite one example: in the collection of Johann Georg von Werdenstein, almost double the size of Knoff's, Venetian editions constitute only thirty-nine per cent, ${ }^{7}$ a small proportion by comparison with the latter.

In order to appreciate the reasons why collection-building occurred on such a colossal scale in the sixteenth century one needs to look at its economic foundations. Music

3 I thank Agnieszka Kubiak from the Musicological Department of the Library for her assistance in my research in Gdańsk.

4 Hartmann, "Musikwissenschaftliches," 390-394.

5 Morell, "Georg Knoff," 103-126.

6 The contents of the collection are listed in ibid., 118-124.

7 Charteris, Johann Georg von Werdenstein, 23-25. 
prints were most often published in the form of partbooks in quarto format, each book containing between twelve and twenty folios. This was probably an optimal solution from the economic point of view, since such small editions would be likely to gain a wider market than large and expensive volumes. According to the inventory of the Accademia Filarmonica in Verona, such a standard print published by Antonio Gardano would, in the mid-sixteenth century, cost on average one lira, the equivalent of a manual worker's pay for less than a full day's work. ${ }^{8}$ Such prints were somewhat more expensive in Royal Prussia at the turn of the 1570s and 1580s. Prices marked on a number of German prints from the Marienkirche collection in Elbląg show that a small music edition cost at that time in the region of eight to ten groschen, equivalent to a day's pay for a bricklayer's apprentice. ${ }^{9}$ In each of these cases we are talking about unbound copies: even an simple cardboard cover would entail a large increase in price, while parchment binding would be significantly more expensive than the print itself. So far as Knoff's collection is concerned, the elegant bindings (to which we will return later) must have considerably increased its value. Additional costs would have been incurred through the need to transport the books from Venice and other distant centres to Gdańsk. Taking into account these circumstances, we might estimate that Knoff invested in his collection the equivalent of at least two years' pay of a bricklayer's apprentice.

The prints date to the period 1568-1601, and their temporal distribution is irregular. It allows us - in conjunction with some other features of the volumes - to distinguish four phases in the creation of the collection (see Table 1). ${ }^{10}$ The first of these might be described as the "foundational" phase. The two bound sets of which it consists contain editions datable to the years 1569-1574 and are in many ways different from those of the later call numbers. On the binding of Ee $2156^{2}$ we find the date " 1574 " and the initials "A G", which most probably refer to the Gdańsk theologian and music lover, Alexander Glaser. Although this set is included in the inventory of prints donated to the Gdańsk Library by Georg Knoff's son Raphael, ${ }^{11}$ it does not contain the note of donation in 1615 appearing in each of the remaining sets. These books were probably transferred to, or bought for, the collection, but they were not fully integrated with it. ${ }^{12}$ The second bound set from the foundational phase (Ee21732) does indeed contain Raphael Knoff's note of donation mentioned above, as well as inscriptions added in his father's hand. It is distinguished from the other sets by the exceptionally small number of prints bound together (only four).

The second phase is represented by ten sets (three of them have been lost; therefore, their inclusion in this phase is hypothetical and based solely on the dating). Basically, these include editions from the first half of the 1580s (the boundary date is the year 1585); however, the majority of them also contain - often as an exception - older editions, reaching back even as far as the year 1568 in the case of Ee3047. This phase is characterized by the presence of a variety of markings testifying that the collection was a private one

8 Lewis, Antonio Gardano, 89.

9 Gancarczyk, Muzyka wobec rewolucji, 85-88; Gancarczyk, La Musique et la révolution, 58-60.

${ }_{10}$ Morell, "Georg Knoff," 109, distinguishes three phases based on purely chronological criteria.

11 Ibid., 117-118.

12 Ibid., 107-108. 
belonging to Georg Knoff. On the bindings we find the collector's initials ("G K"), and on the paste-down sheets (as in Ee2173²) contents lists and aphorisms entered by Knoff himself. For this reason, one might describe this phase as one of "individualization."

Table 1 The phases of building the Knoff collection

\begin{tabular}{|l|r|r|}
\hline Phase & Print Dating & \multicolumn{1}{|c|}{ Call Numbers of the Bound Sets $^{\star}$} \\
\hline 1. Foundational phase & $1569-1574$ & Ee2156', Ee2173² \\
\hline 2. Individualization phase & $1568,1572-1585$ & Ee1184, Ee2273, Ee2318, Ee3047, Ee1720, Ee2639, Ee2789, \\
& & Ee3044, Ee2125²,Ee2371 \\
\hline 3. Objectivization phase & $1580,1582-1589$ & Ee1815, Ee2456, Ee2206, Ee2380, Ee2628, Ee2975, Ee1189, \\
& & Ee1638, Ee1856, Ee1982, Ee2932 \\
\hline 4. Recurrence phase & $1589,1595-1601$ & Ee1931, Ee2027²,Ee1370 \\
\hline
\end{tabular}

* Call numbers of the missing sets are indicated by italics. They are quoted according to the sequence established in Morell's inventory ("Georg Knoff," 118-124). The call numbers omit a reference to the library format, which is identical for all the sets $\left(8^{\circ}\right)$.

The third phase is represented by the eleven call numbers containing prints from the years 1580 and 1582-1589. The temporal spread of the editions within each individual set is much narrower than in the second phase; in a number of them we find prints published within two or three years of each other. It is also the most heavily Italian phase $(92 \%$ of the editions are of Italian provenance). This phase brings with it a depersonalization of the collection: Knoff's initials disappear from the bindings, ${ }^{13}$ and the practice of writing contents lists and aphorisms on the paste-down sheets is abandoned. In two of the sets (Ee1815 and Ee2380) we merely find - as before - a numerical ordering of the prints they contain added by the collector on the title pages. This phase might be referred to as one of "objectivization", not only in view of the absence of marks indicative of ownership, but also on account of the almost wholesale manner in which the editions were obtained, the overwhelming majority of them coming from the same centre (Venice) within a narrow time-frame (1584-1589).

The fourth, final phase consists of prints bound in 1615: that is, ten years after the death of Georg Knoff, as indicated by the dates embossed on the bindings. These editions date to the years 1595-1601 (with the exception of a single print from 1589), and many more of them originate from German printers. We find here no entries in the hand of Georg Knoff but merely contents lists and notes of donation made by his son. Since this phase marks a return after a gap of a number of years, we may describe it as the "recurrence" phase.

Assessing the collection as a whole leads to the conclusion that Knoff's enthusiasm for collecting fell mainly within the 1580s. In 1590 this enthusiasm suddenly ceased and remained absent for a period of several years, with no prints dating to this period. Since we know little about Knoff's life, it is difficult to say what might have brought about this lacuna. One may merely draw attention to the fact that the 1580 s were the decade that saw the largest number of prints of polyphonic music published relative to the rest of the entire

13 According to Martin Morell's list (“Georg Knoff," 121-122). Knoff's initials appear on the covers of Ee2456, Ee2206, Ee2380 and Ee2975. Personal inspection did not confirm their presence. 
sixteenth century. ${ }^{14}$ This was also the golden age of the printing firm of Angelo Gardano, ${ }^{15}$ which produced the largest number of prints in Knoff's collection. The mid-1580s were also a period when Gdańsk was particularly prosperous; this prosperity, although it had a tendency towards continuous increase, encountered a number of setbacks, such as the epidemics of 1587-1589 and the poor harvest and consequent price rises of $1589 .{ }^{16} \mathrm{We}$ cannot say whether these events had a dampening effect on Knoff's enthusiasm for collecting, or whether some unknown personal factors played their part.

The question now arises: how did prints, particularly the Italian ones, find their way to distant Royal Prussia? As we know, an important part in the distribution of books was played by book fairs, particularly that in Frankfurt am Main. An excellent illustration of this is provided by the inventory of sheet music imported from Frankfurt to Poland in 1602 for the bookselling establishments of Zacheus Kesner in Kraków and in Lublin. This inventory lists ninety-one editions identified by title (numbering between one and four copies), and 284 copies of music prints in quarto format, the content of which is not given. ${ }^{17}$ Among the identified titles Venetian editions constitute thirty per cent of the items. The problem is, however, that during the last quarter of the sixteenth century - as we learn on the basis of the surviving lists - the items offered at this fair included prints from Gardano or Scotto only sporadically..$^{18}$ It was much easier to purchase prints from Nuremberg or Munich, which offered for sale the majority of the German editions preserved in the Knoff collection. Independently of the fairs in Frankfurt and other cities, there also existed the possibility of importing prints via a network of booksellers. We learn about some of the principles on which this system of distribution operated from the trading records of Christopher Plantin from Antwerp, who found customers throughout Europe.$^{19}$ It seems, however, that Georg Knoff had some special channel for obtaining Italian prints that significantly shortened the chain of intermediaries. A number of features in his collection point to this conclusion.

The method employed for ordering the prints was to combine them into larger sets which, in the case of Knoff's collection, contain from four to nineteen editions. The initial criterion for combining prints into one bound set was their format. Since we are dealing here only with quarto format, the sole significant distinction was between upright and oblong orientation. The essential criterion adopted for positioning the prints within the framework of an individual set was the number of partbooks: prints with the smallest number of parts were placed at the beginning, and those with the largest number at the end. ${ }^{20}$ Over and above these external features Knoff ordered the prints according to the criterion of provenance. Two sets contain German editions (Ee3047, Ee2027²), while the remainder group together Italian prints, supplemented by prints of different origin only on

${ }^{14}$ Gancarczyk, Muzyka wobec rewolucji, 76; Gancarczyk, La Musique et la révolution, 50.

15 Agee, Gardano Music Printing Firms, 63.

16 Pelc, Ceny w Gdańsku, 56-58.

${ }^{17}$ Czepiel, "Zacheus Kesner," 23-69.

${ }^{18}$ See Göhler, Verzeichnis der in den Frankfurter und Leipziger Messkatalogen.

${ }^{19}$ See Vanhulst, "Suppliers and Clients of Christopher Plantin," 558-604.

${ }^{20}$ See Morell, "Georg Knoff," 106 (Table 5.1.). 
exceptional occasions. What is striking here is the observable tendency to bind together editions from specific printing shops. The majority of the sets are dominated by prints from Angelo Gardano, and two of them contain no editions from any other printers (Ee2371, Ee1815). We also encounter sets containing prints from Scotto (Ee2173², Ee1184) where there are no items from Gardano, as well as one bound set containing a few editions from Scotto, Amadino and Vincenti and only a single edition from Gardano (Ee1189). At the same time, it is difficult to discern any tendency to arrange the prints according to the criterion of the type of repertory, apart from the obvious principle of binding together items belonging to the same publishing series. We find within the same sets secular and sacred compositions, and serious madrigals cheek by jowl with lighter Italian repertory. It is also worth noting that prints from particular sets - especially from the third phase of collection-building - often span only a short segment of time. This is particularly striking in the case of Ee1815, where out of thirteen editions twelve were printed in 1586, and also in Ee1982, where the prints date from a period between June 1588 and April 1589.

This manner of binding the sets leads us to suppose that we are dealing with a collection formed by purchasing not single editions but largish batches. The binding together of prints originating from the same location and from a similar period suggests that the purchases were made through fairly direct contact with Italian printing shops. ${ }^{21}$ Otherwise, it seems, the content of the sets would have been more mixed in terms of both provenance and chronology, while the proportion of German or Flemish prints would have been significantly higher. Perhaps this kind of purchase was facilitated by catalogues of books for sale, such as the Indice delli libri di musica published by Angelo Gardano in 1591.22 We may suppose that Georg Knoff did not build up his collection by visiting a local bookshop or the fairs. Nor would he have made use of a chain of intermediaries. Instead, he probably had an agent who purchased prints for him directly in Italy. ${ }^{23}$

This hypothesis becomes more likely when we take into account the trading contacts of Gdańsk, then the most important port on the Baltic. During the second part of the sixteenth century it was undergoing a period of great expansion: in 1583 as many as 72.8 per cent of ships sailed out of Prussia via the Sound to the Low Countries, France, Spain, Portugal and Italy. Poor harvests in Southern Europe in the second half of the 1580s intensified even more the direct and reciprocal trade between Gdańsk and such centres as Venice. Polish grain was exported, while wine and luxury goods were imported. ${ }^{24}$ Among these luxury goods may well have been books, including the music prints ordered by Georg Knoff. An alternative transport route might have been overland - faster but more expensive - leading north via Innsbruck, Vienna and Kraków. ${ }^{25}$

The key question remains to be answered: what could have been the motive for such an enormous effort to amass canzonette and madrigals in distant Gdańsk? The presence

${ }^{21}$ Cf. Morell, "Georg Knoff,” 114-115; Leszczyńska, "Beginnings of Musical italianità,” 7.

${ }^{22}$ Agee, Gardano Music Printing Firms, 360-405.

${ }^{23}$ These remarks do not apply to German, Flemish and Prussian prints, which were undoubtedly obtained in a different manner.

${ }^{24}$ See Bogucka, "Gdańsk - największy port Bałtyku," 484.

${ }^{25}$ Morell, "Georg Knoff," 114-115. 
of Italian editions in the collection should not in itself be surprising since, as we know, in the sixteenth century almost every second edition of polyphonic music originated from the Venetian printing presses, and during the 1580s the share of Venice in the production of prints of this type amounted to 54.2 per cent (and 66.6 per cent for Italy as a whole). ${ }^{26}$ In Poland, including the area of Royal Prussia, we find many traces of the presence of madrigal repertory, which even as early as the second half of the sixteenth century was undergoing a variety of modifications and adaptations. ${ }^{27}$ It is sufficient to mention that the members of Elbląg's Convivium musicum sang the balletti of Giovanni Giacomo Gastoldi, as testified by the manuscript dating from around 1600 which they employed, and in which these works were copied together with their original Italian texts. ${ }^{28}$ However, the scale of Knoff's Italian-oriented interest is puzzling: perhaps his personal taste played an important part here, as well as a facility to obtain the prints directly from Italy, as mentioned earlier.

In the literature on the subject produced so far, including the study by Martin Morell, we find information about Georg Knoff's musical competence, according to which he is supposed to have been not only a bibliophile but also a performer. ${ }^{29}$ Evidence for this is presumed to be provided by the handwritten corrections appearing in the prints, as well as - indirectly - other kinds of evidence. It seems, however, that to make this assumption when interpreting the collection rests on somewhat flimsy premises.

The prints in Knoff's collection show few traces confirming their use in musical performance. Some of the corrections originating from the sixteenth century may well be - as Morell has correctly pointed out - publishers' emendations. ${ }^{30}$ These are distinguished by careful calligraphy as seen, for example in the added minim b and the syllable "-ce" in the print containing madrigals by Constanzo Porta (Ee2456/5, Il quarto libro de madrigali a cinque voci (Venice: Angelo Gardano, 1586), Cantus, p. 1). Clear marks left by actual users occur in only two sets. The first of these is set Ee2156 ${ }^{2}$, the one that originally belonged to Alexander Glaser and was most probably used by him. In this we find a variety of corrections in the Premier livre des chansons (Ee2156 $2 / 1$ [RISM 1570 5 ]) and the Liber primus sacrarum cantionum (Ee2156 $/ 1$ a [RISM 15697 ]). Moreover, at the end of this set we find a handwritten supplement - a copy of the madrigal In dubbio di mio stato by Paolo Animuccia - written out before the partbooks were bound in 1574 . The second set in which we find unquestionable and numerous traces of use is Ee20272, which belongs to the fourth, final phase of building the collection. These traces occur in the print Cantiones sacrae of Hans Leo Hassler (Ee2027²; Nuremberg: Paul Kauffmann, 1597), which was clearly of particular interest both at the turn of the sixteenth and seventeenth centuries (with inscriptions in ink), and in the twentieth century (with inscriptions in pencil, including ones in German). It is difficult to tell whether these older entries - which concern, for example, the duration of rests, the names of voices, or a missing flat sign - were made

${ }^{26}$ Gancarczyk, Muzyka wobec rewolucji, 76; Gancarczyk, La Musique et la révolution, 50.

${ }^{27}$ Cf. Jeż, Madrygat w Europie pótnocno-wschodniej; Leszczyńska, "Beginnings of Musical italianità," 1-11.

${ }^{28}$ Leszczyńska, "Thannenwald," 107.

${ }^{29}$ See Morell, "Georg Knoff," 110.

${ }^{30}$ Ibid. 
in the hand of Georg Knoff or that of another person such as his son. In the remaining sets, particularly those constituting the core of the collection (i.e., the second and third phases of its creation), original traces of use are almost imperceptible. However, we find here inscriptions made by twentieth-century users of the prints: for example, numerals quantifying the number of semibreves. Morell interpreted these as entries made in Knoff's hand, ${ }^{31}$ but closer analysis leaves no doubt about their more modern origin (see Figs. 1 and 2). This origin is shown by the implement used for writing (most often pencil) and the ductus of the handwriting (clearly different from Knoff's), as well as the purpose of the entries (enumerating semibreves and inserting occasional strokes and other marks, all of which point to someone's struggle to transcribe the works into modern notation). Only some of the crosses entered in ink under the notes may date from Knoff's time, but this is insufficient to establish that his collection was used for musical performance.

Evidence for Knoff's musical competence might be sought in Johannes Eccard's dedication on the title page of the Tenor partbook of his Newe Lieder (Ee1856):

Praestanti Viro, Domino Georgio Knoff, patricio Gedanensi, insigni Musico, nec non Musicorum omnium patrono celeberrimo, domino suo et amico, dono dedit author.

To Esteemed Master Georg Knoff, patrician of Gdańsk, a distinguished musician and also a most famous patron to all musicians, his master and friend, this gift is made by the author.

The kapellmeister from Königsberg describes Knoff as a "distinguished musician." However, it appears - taking into account the understanding of the term "musicus" at that time and the rhetoric typical of a dedication - that this is not equivalent to the term "musician" as we understand it today. In this particular context the term is more likely to refer to someone who possesses a certain level of knowledge about music and not just the purely practical skill of singing, and this is how the term was understood in the writings of Franchinus Gaffurius and other sixteenth-century treatises. ${ }^{32}$ Clearly, this reference to Knoff as a musicus does not exclude the possibility that he was a skilled singer or instrumentalist, but neither does it identify him as a professional or professionalstandard performer.

However, evidence for Knoff's competence as a practising musician could possibly be provided by the handwritten copy of missing pages from the anthology Sacrarum symphoniarum continuatio (RISM $1600^{2}$ ), which constitutes part of another collection from Gdańsk, formerly belonging to the Marienkirche and currently held by the Gdańsk Library of the Polish Academy of Sciences (BibMar q82-87). ${ }^{33}$ Morell hypothesizes that Georg Knoff likewise had a part in creating this collection of music prints, and he takes as evidence of this - among other things - the manuscript of the missing pages of the Quinta

${ }^{31}$ Ibid.

32 Witkowska-Zaremba, Ars musica w krakowskich traktatach, 92-100.

${ }^{33}$ The individual partbooks from this collection, lost during the Second World War, were recently identified at the National Museum in Warsaw; see Gancarczyk, "Sixteenth- and SeventeenthCentury Music Prints," 57-59 and 63-65. 
vox in the example of the anthology referred to above, which is copied in his handwriting. ${ }^{34}$ In my view, to identify Knoff as the copyist of this manuscript is highly dubious. We need merely note the completely different manner of writing the letters "b", "d", "l" and the ligature "ae," as well as to compare the words appearing both in the autograph inscriptions and in the copy from the Marienkirche collection, which provide particularly useful comparative material ("Gabriel[is]", "David[ici]", "vitae"). The writing of the word "DEO" exhibits some similarity, but this is very insignificant when set against the other details of the Marienkirche source's handwriting, which - notwithstanding the handwriting's different functions in the manuscripts being compared, which creates difficulties for comparative analysis - differ too much to have been the work of the same scribe. ${ }^{35}$

As this discussion has demonstrated, we do not in fact have unequivocal evidence that Knoff's prints were ever used in performance, nor even confirmation of his practical musical skills beyond those acquired via the standard musical education of a member of the patrician class. There is much to suggest that this collection was not created with the aim of singing or playing the music contained in the prints composing it. Most probably, it was not aimed either at obtaining material for specific performances, since we have a puzzling absence of evidence indicating that Knoff's prints influenced the musical repertory of Royal Prussia in any way. ${ }^{36}$ Nor was it a mere accumulation of objects of practical value: it was a collection sensu stricto: one devoid of any utilitarian function.

Such an interpretation seems to accord with the sense of the notes of donation entered (in several variants) by Raphael Knoff on the paste-down sheets of individual sets (see Fig. 1). They speak of the collection of books having been created because of his father's passionate interest ("studium"):

In Bibliothecam Amplissimi Senatus Gedanensis hosce libros parentis sui studio conquisitos 1.[ibenter] v.[olente] d.[atos] conferebat Raphael Cnofius. Anno 1615. Mense Septembri.

To the Library of the Most Illustrious Senate of Gdańsk, these books, collected by his father on account of his passion, [donated freely and of his own volition] were presented by Raphael Knoff in the year 1615, in the month of September. ${ }^{37}$

${ }^{34}$ Morell, "Georg Knoff," 116.

${ }^{35}$ I find it difficult to share Morell's assumption that the differences in the handwritings under comparison result from the fact of copying notes from a print. The shape of the letters "d" or "l", with the slant of the upper part of the strokes to the right, and the form of the letter "s" show that the style of writing represents more the scribe's autonomous choices than any attempt to imitate printed lettering (a comparison of the diamond-shaped note-heads in the print and the round ones in the manuscript leads to a similar conclusion). The underlaying of words to notes influences such important aspects of handwriting as the connection and spacing of letters, for which reason I concentrate on the shapes of individual letters and syllables when making comparisons.

${ }^{36}$ Leszczyńska, "Beginnings of Musical italianità," 6.

${ }^{37}$ The word "conquisitos" is replaced in some notes by the words "comparatos", "collectos" or "aquisitos." I thank Professor Bartosz Awianowicz from the Nicolaus Copernicus University in Torun for his proposed resolution of the abbreviation "l.v.d." 
According to Krzysztof Pomian, who has researched into the phenomenon of collecting from the sixteenth to the eighteenth centuries, a key feature of the objects that make up a collection is that they are excluded - temporarily or permanently - from practical use. These objects need to be subject to special protection and arrangement so that despite their multiplicity one is able to discern that they belong to a single category. It is important to assign to them features that make them well adapted for viewing, since creating a collection presupposes the participation of a public, defined in a variety of ways. Hence a collection should be regarded as an autonomous creation, transported beyond the boundaries of utility: this is a creation that functions as a prestigious representation drawing the viewer through what is visible towards the sphere of what is not visible. ${ }^{38}$ Although Pomian explores mainly the phenomenon of cabinets of curiosities and collections of works of art, it is worth quoting what he says about libraries:

[...] the purchase of works of art, the creation of libraries or collections, is one of the procedures which transform utility into significance and allow the person who occupies a high rank in the hierarchy of wealth to achieve an appropriate position in the hierarchy of good taste and knowledge, since the elements of the collection are [...] signifiers indicating membership of a social class or indeed superiority. ${ }^{39}$

These remarks seem very appropriate in relation to Georg Knoff's collection. As noted earlier, it was preserved from utilitarian application. Traces left by possible performers occur in reality only in a few prints, and these few do not even belong to the main phases of the collection's formation (i.e., phases two and three). Knoff took care to have the collection properly housed and ordered by having the editions bound. He also made sure that it was invested with features inviting admiration - not so much of the music itself but rather of the volumes in which it was contained.

The visual qualities of Knoff's collection have not so far been the subject of much attention, although the artistic value of some of the bind"0ings has already been noted. ${ }^{40}$ Examining this phenomenon more closely, we observe that each of the surviving bound sets is different in appearance. We may distinguish nine elements that bring about this differentiation:

- upright or oblong orientation

- a soft or hard binding

- the presence of ornamentation on the binding

- the kind of ornamentation for the binding

- the use of dye for the leather

${ }^{38}$ Pomian, Collectionneurs, amateurs, 293-296.

39 “'L'achat d'œuvres d'art, la formation de bibliothèques ou de collections, est une des opérations qui, transformant l'utilité en signification, permettent à quelqu'un de haut placé dans la hiérarchie de la richesse d'occuper une position correspondante dans celle du goût et du savoir, les pièces de collection étant [...] des insignes d'appartenance social, sinon de la supériorité." Pomian, Collectionneurs, amateurs, 53.

${ }^{40}$ See Ogonowska, Oprawy zabytkowe, figs. 28-30. 
- the presence of ribbons for tying the books and their colour

- the application of punching to the edges of folios and the patterns used

- the application of dyeing to the edges of folios and its colour

- the colour of the headband

Visually closest to each other are the sets Ee1815 and 2456, which differ in only one element (the orientation of the folios), whereas all the others are identical (hard binding with ornamentation, brown in colour, tied with red ribbons, with red edges to the folios, no punching). The remaining sets differ in a number of respects: we find hard bindings with very rich ornamentation and white in colour (Ee2318, Ee3044), as well as soft ones without ornamentation and seemingly modest but nevertheless striking in their colouring (for instance, in Ee2975 the parchment binding is dyed brick red, the ribbons are green, the punching on the edges of the folios is in blue, and the headband is golden yellow). These techniques made prints from Knoff's collection attractive not only because of their origin and elevated repertory but also on account of their external features. They looked impressive on the shelves (the books' spines were likewise ornamented and dyed), and even just gazing at the covers must have evoked satisfaction and admiration. Differentiation by colouring and type of ornamentation also had an ordering function: it made it easier to assign a given partbook to a particular set. One need hardly add that the visual attractiveness of the prints is much less obvious today than must originally have been the case, not only through damage suffered by the bindings (particularly the spines), but also because of wear to the dyed leather, the excision of ribbons and the discolouration of the headbands by dirt.

The puzzling procedure adopted for set Ee $2173^{2}$ from the foundational phase should similarly be interpreted in terms of the visual effect produced. At the time when it was bound (ca. 1578) ${ }^{41}$ Knoff had most probably not yet established a reliable method of obtaining prints, hence this print contains only four editions. These were bound together with a number of fascicles of blank folios, a feature that augments the thickness of the individual partbooks. These folios were never filled in any way, and display no signs suggesting that they were intended for copying music or making annotations. The sole explanation for binding them together with the prints is a desire to increase the bulk of the books for the sake of their visual appearance. This simple procedure ensures that set Ee $2173^{2}$ does not differ in its number of folios from the later volumes in the collection, which - with the exception of Ee1856 (Eccard's Newe Lieder) - are all more or less of the same thickness. We may add that the binding of the prints was carried out in Gdańsk; in the majority of cases this is unequivocally shown by the watermarks on the paper used by the bookbinders, which depict different variants of the "fish in a circle" motif. ${ }^{42}$ This shows that Knoff had the opportunity to influence directly the appearance of his collection.

${ }^{41}$ Next to the binding we find paper with a watermark datable to 1578; see Siniarska-Czaplicka, Filigrany papierni, no. 1207.

${ }^{42}$ See Siniarska-Czaplicka, Filigrany papierni, nos. 1197-1198, 1204-1207; Siniarska-Czaplicka, Katalog filigranów, nos. 1258-1264. The only sets where the "fish in a circle" sign does not appear are Ee2156², Ee1931 and Ee2027². 
The collection is thus characterized by a series of features indicating that beyond its contents its appearance held significance. Its creation was motivated not only by the desire to accumulate interesting music prints but also (and perhaps primarily) to define the social status of the collector. In this way a patrician ranking high in the economic hierarchy could signal his elevated position in the "hierarchy of good taste and knowledge." In addition to the mentioned characteristics of the editions and bindings one discovers further signs that this was the owner's aim in many sets belonging to the first two phases of the collection's formation.

As early as set Ee $2173^{2}$, from the foundational phase, an emphasis is placed on Knoff's ownership of the collection. We find there the legend "Sum Georgij Knophij", where the book tells us in the first person: "I belong to Georg Knoff." All the bindings from the second phase, that of "individualization," carry the owner's initials "G K" and the date - perhaps in imitation of Alexander Glaser, who marked set Ee $2156^{2}$ in a similar way (with his initials and the date). In addition, the paste-down sheets of these books (usually in the Tenor) carry a number of aphorisms parading Georg Knoff's erudition in the areas of classical literature, Latin and Italian as well as testifying to his piety. The most frequent aphorism, since it makes several appearances in sets Ee21732 and Ee2318, is an elegiac distich elaborating the well-known maxim "vive ut vivas" ("live that you may live"). This served as a kind of family motto, ${ }^{43}$ as expressed by the abbreviation "V.V.V." used in set Ee21732:

V.V.V. / Sic Vive Vt longum Vivas, nec vivere / Mundo.

Malis, quam tua sit vita dicata / DEO.

Were you to live in such a way as to live for long, do not live for the world.

It is better that your life should be devoted to GOD.

Another elegiac distich appears on the paste-down sheet of the Tenor book in set Ee1184 (see Fig. 1):

Passibus incertis errat fortuna sub aevo.

Dum mala prae foribus spem melioris habe.

Fortune in life wanders with uncertain steps.

So long as evil lies outside the door, hope for that which is better.

On this occasion we have a reference to a line in Ovid's Tristia (book V). ${ }^{44}$ Significantly, the same quotation from Ovid accompanies the image of Fortune embossed on the bindings of partbooks in set Ee2318.

${ }^{43}$ Knoff once again entered this distich in the book of the St Reinhold Brotherhood from 1590 on the occasion of the acceptance as a member of his newborn son Raphael. Morell, "Georg Knoff," 111.

44 "Passibus ambiguis Fortuna volubilis errat.” I thank Professor Bartosz Awianowicz for his help in interpreting these distichs. 
In Ee2639 - likewise from the individualization phase - we find a short quotation from Virgil's Aeneid (book I): "Olim meminisse iuvabit" ("perhaps it will be pleasing to reminisce about this one day"), while in set Ee2789 Knoff entered the Italian proverb:

Belle parole e tristi fatti

Ingannano i savi e li matti.

Beautiful words and sad affairs

Deceive both the wise and the foolish.

These maxims collectively testify to Knoff's humanistic education, which he perhaps obtained at the Academic Gymnasium in Gdańsk, established in $1558 .{ }^{45}$ They contain reflections on the transience and vanity of this world and the typically Christian entrustment of oneself to God. In the first maxim, which seems to be central, Knoff contrasts (also through the manner of their writing) the words "mundo" and "DEO", making the second distinctive by the use of capitals. The pious collector reminds us that our life should be devoted to God and not only to the affairs of this world. The library that he created was capable of ensuring both splendour in life and remembrance after death, a fact of which Knoff was undoubtedly aware. Nonetheless, in conformity with the idea of Christian humility the collector, after this initial phase of individualization, ceased to mark the prints with outward signs of his ownership. Might he have sought by this to follow the path of Lutheran orthodoxy?

Accumulating a sizeable collection of music prints created an excellent opportunity to give evidence of possessing erudition, education, good taste and wide horizons. The exceptionally high proportion of Venetian editions lent the collection the distinction of uniqueness, thereby increasing its cultural and material value. It also secured a place for Georg Knoff within the boundaries of the highly regarded Italian culture, which had provided a model for Poland even as early as the time of Sigismund I the Old (king of Poland during the years 1507-1548). Obtaining prints from distant centres was undoubtedly facilitated by the extensive trade links that Gdańsk enjoyed: once again, the routes of cultural contact coincided with those through which goods and capital flowed. In the light of the above discussion, it seems obvious that Knoff's aim was not merely to accumulate madrigals and canzonette: it was equally to create a prestigious representation of his social position expressed through the provenance and visual aspects of his collection. The goal of obtaining an elevated position within not only the economic but also the cultural hierarchy had been achieved. ${ }^{46}$

${ }^{45}$ See Budzyński, "Dawne humanistyczne Gimnazjum,” 7-69. Georg Knoff’s sons were educated at this Gymnasium. See Morell, "Georg Knoff," 111.

${ }^{46}$ The text of this article was translated into English by Zofia Weaver. 


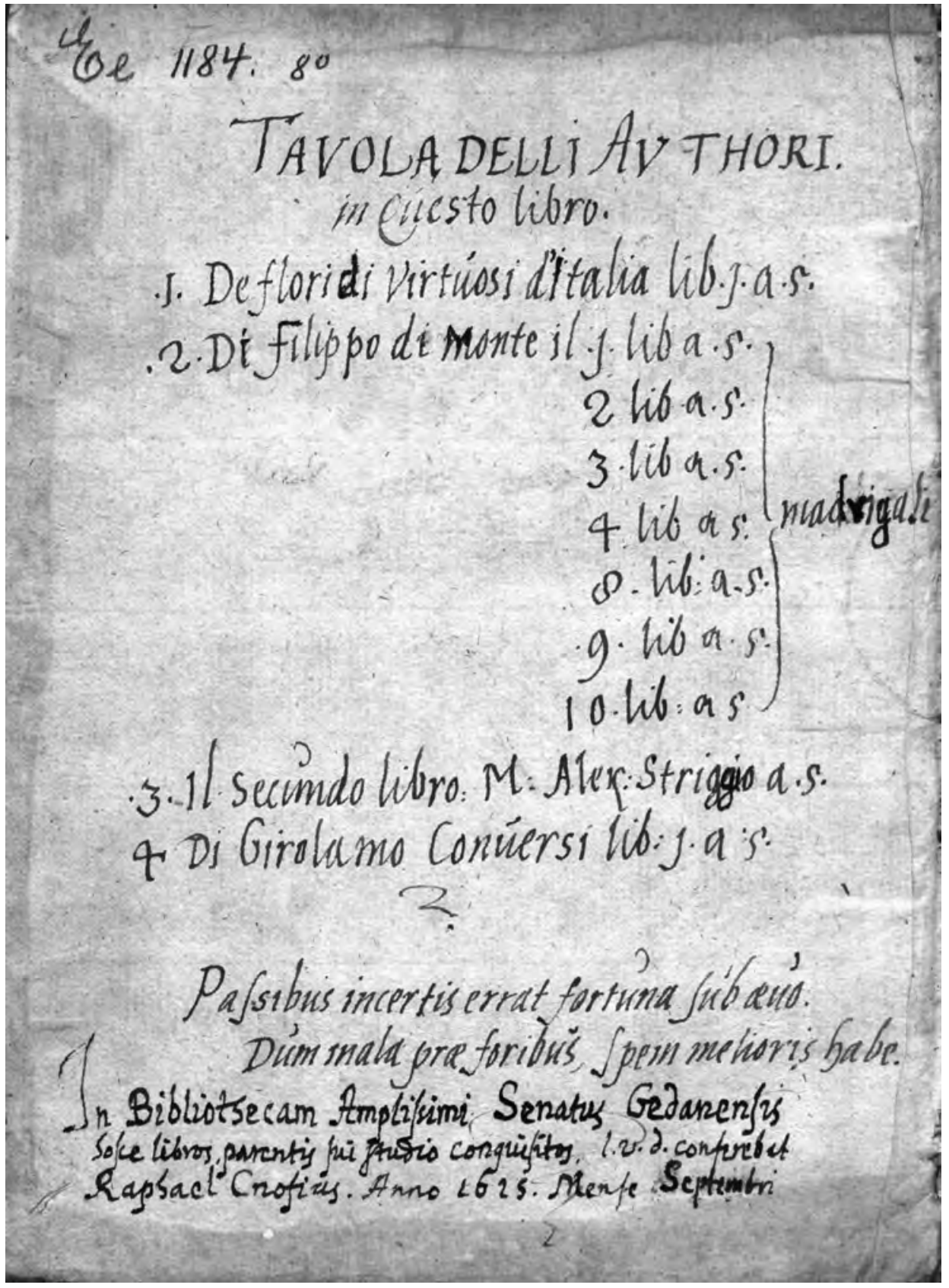

Figure 1 Ee1184, Tenor, paste-down sheet of the cover: Autograph inscriptions of Georg Knoff (contents list and distich) and his son Raphael (note of donation below); (Polska Akademia Nauk, Biblioteka Gdańska, call no. Ee1184 8º reproduced with kind permission). 


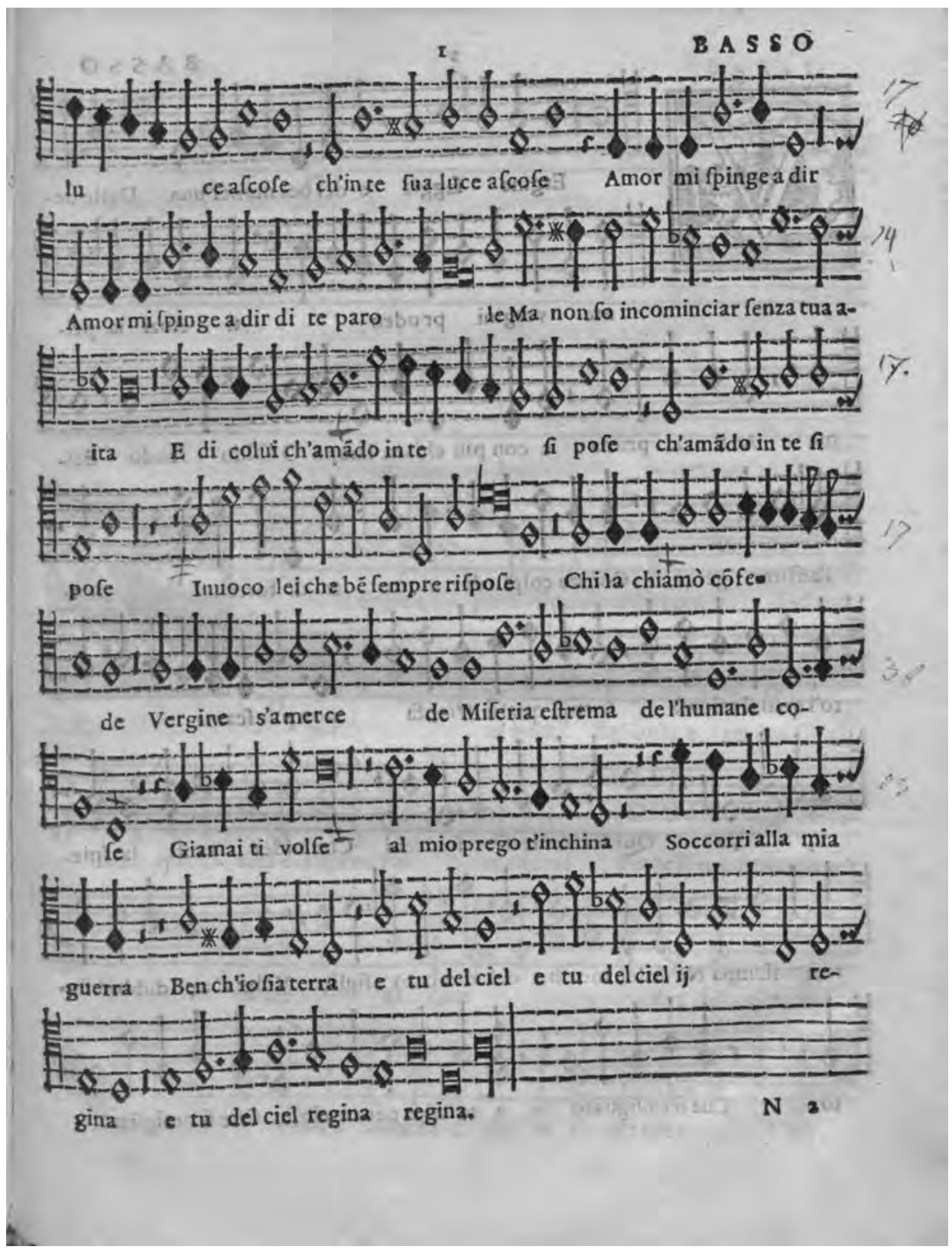

Figure 2 Ee1720/8, Bassus, s. 1: Twentieth-century additions (Polska Akademia Nauk, Biblioteka Gdańska, call no. Ee1720/8 8; reproduced with kind permission). 


\section{Bibliography}

Agee, Richard J. The Gardano Music Printing Firms, 1569-1611. Rochester: University of Rochester Press, 1998.

Bernstein, Jane A. "Buyers and Collectors of Music Publications: Two Sixteenth-Century Music Libraries Recovered." In Music in Renaissance Cities and Courts: Studies in Honor of Lewis Lockwood, edited by Jessie Ann Owens and Anthony M. Cummings, 21-34. Warren, MI: Harmonie Park Press, 1997.

Budzyński, Józef. "Dawne humanistyczne Gimnazjum Akademickie w Gdańsku w XVI i XVII wieku." In Gdańskie Gimnazjum Akademickie, vol. 4, W progach Muz i Minerwy, edited by Zofia Głombiowska, 7-69. Gdańsk: Wydawnictwo Uniwersytetu Gdańskiego, 2008.

Chapman, Catherine Weeks. "Printed Collections of Polyphonic Music Owned by Ferdinand Columbus.” Journal of the American Musicological Society 21, no. 1 (1968): 34-84. Charteris, Richard. Johann Georg von Werdenstein (1542-1608): A Major Collector of Early Music Prints. Sterling Heights: Harmonie Park Press, 2006.

Cieślak, Edmund, ed. Historia Gdańska. Vol. 2, 1454-1655. Gdańsk: Wydawnictwo Morskie, 1982.

Czepiel, Tomasz. "Zacheus Kesner and the Music Book Trade at the Beginning of the Seventeenth Century: An Inventory of 1602.” Musica Iagellonica 2 (1997): 23-69.

Gancarczyk, Paweł. "Sixteenth- and Seventeenth-Century Music Prints at the National Museum Library in Warsaw." Musicology Today 4 (2007): 57-66.

—_— Muzyka wobec rewolucji druku: przemiany w kulturze muzycznej XVI wieku. Toruń: Wydawnictwo Naukowe UMK, 2011.

___. La Musique et la révolution de l'imprimerie: les mutations de la culture musicale au XVIe siècle. Translated by Wojciech Bońkowski. Lyon: Symétrie, 2015.

Göhler, Karl Albert. Verzeichnis der in den Frankfurter und Leipziger Messkatalogen der Jahre 1564 bis 1769 angezeigten Musikalien. Leipzig: C.F. Kahnt Nachfolger, 1902. Reprint, Hilversum: Knuf, 1965.

Hartmann, Karl-Günther. "Musikwissenschaftliches aus der ehemaligen Danziger Stadtbibliothek." Die Musikforschung 27, no. 4 (1974): 387-412.

Jeż, Tomasz. Madrygat w Europie północno-wschodniej: dokumentacja - recepcja przeobrażenia gatunku. Warsaw: Semper, 2003.

Leszczyńska, Agnieszka. "Thannenwald - the Lost Manuscript from Elbląg/Elbing Partially Rediscovered." Hudební věda 51, nos. 1-2 (2014): 105-114.

. "The Beginnings of Musical italianità in Gdańsk and Elbląg of the Renaissance Era.” Musicology Today 10 (2013): 1-11. doi:10.2478/muso-2014-0001.

Lewis, Mary S. Antonio Gardano, Venetian Music Printer 1538-1569: A Descriptive Bibliography and Historical Study. Vol. 1, 1538-1549. New York: Garland Publishing, 1988.

Morell, Martin. "Georg Knoff: Bibliophile and Devotee of Italian Music in Late SixteenthCentury Danzig." In Music in the German Renaissance: Sources, Styles, and Contexts, edited by John Kmetz, 103-126. Cambridge: Cambridge University Press, 1994. 
Ogonowska, Ewa. Oprawy zabytkowe i artystyczne XIII-XIX wieku w zbiorach Biblioteki Gdańskiej Polskiej Akademii Nauk / Historic and Artistic Bindings 13th-19th Century in Collection of Gdańsk Library of the Polish Academy of Sciences. Gdańsk: Wydawnictwo Gdańskie, 1993.

Pelc, Julian. Ceny w Gdańsku w XVI i XVII wieku. Lviv: Kasa im. Rektora J. Mianowskiego, 1937.

Pomian, Krzysztof. Collectionneurs, amateurs et curieux: Paris, Venise; XVIe-XVIIIe siècle. Paris: Gallimard, 1987.

Siniarska-Czaplicka, Jadwiga. Filigrany papierni położonych na obszarze Rzeczypospolitej Polskiej od poczatku XVI do połowy XVIII wieku. Wrocław: Ossolineum, 1969.

—_ Katalog filigranów czerpalni Rzeczypospolitej zebrane z papieru druków tłoczonych $w$ latach 1500-1800. Łódź: Stowarzyszenie Inżynierów i Techników Przemysłu Papierniczego, 1983.

Vanhulst, Henri. "Suppliers and Clients of Christopher Plantin, Distributor of Polyphonic Music in Antwerp (1566-1578)." In Musicology and Archival Research: Colloquium Proceedings Brussels 22-23.4.1993, edited by Barbara Haggh, Frank Daelemans and André Vanrie, 558-604. Brussels: Archives et Bibliothèques de Belgique, 1994.

Witkowska-Zaremba, Elżbieta. Ars musica w krakowskich traktatach muzycznych XVI wieku. Kraków: Polskie Wydawnictwo Muzyczne, 1986. 


\section{ZBIRKA GEORGA KNOFFA V GDANSKU \\ OPAZKE O ZBIRANJU IN ŠIRJENJU GLASBENIH TISKOV}

\section{Povzetek}

Georg Knoff (u. 1605) - patricij iz mesta Gdansk na Poljskem - je proti koncu 16. stoletja ustvaril zbirko, v kateri je imel 267 glasbenih tiskov iz let med 1568 in 1601. Večinoma so bili to italijanski tiski ( $82 \%$ ), pretežno iz beneške tiskarne Angela Gardana, po vsebini pa je šlo za madrigale in lažje posvetne skladbe. Lastnik je večino tiskov dal zvezati v obsežnejše glasovne zvezke, ki so dobili tudi svojo skupno oznako. Na podlagi kronologije izdaj in zunanje podobe tiskov ugotavljamo, da se je celotna zbirka izoblikovala v štirih korakih. Leta 1615 je Knoffov sin Raphael zbirko poklonil knjižnici mestnega sveta v Gdansku. Večji del tiskov se je ohranil vse do danes in se nahaja v knjižnici Poljske akademije znanosti v tem mestu.

Avtor razprave predvideva, da je prvotni zbiralec večino tiskov pridobil neposredno preko svojih znancev v Italiji. O tem priča dejstvo, da so tiski urejeni po svojem krajevnem izvoru (urejevalec npr. razlikuje med »italijanskimi« in »nemškimi« tiski), pa tudi to, da so skupaj zvezane beneške izdaje iz sorazmerno ozkega časovnega obdobja. To hipotezo potrjuje tudi dejstvo, da je imelo konec 16. stoletja mesto Gdansk razvite trgovske stike z Italijo, pa tudi z drugimi evropskimi deželami, ki so uvažale poljsko žito.

Tiski kažejo le redke znake uporabe in ni povsem jasno, do kolikšne mere je bil Knoff sploh zmožen to glasbo sam izvajati. Prav zato se zdi, da tiske ni zbiral za izvajanje, temveč bolj v smislu potrjevanja svojega statusa poznavalca z dobrim okusom in znanjem. Po antropoloških raziskavah zbirateljstva (Krzysztof Pomian) je Knoffova zbirka avtonomna kreacija s svojim skritim pomenom, ki ga lahko razberemo iz vidnih elementov, med katerimi so na primer presenetljivo lepe platnice in latinski napisi na njih. Razprava polemizira s prejšnjimi raziskovalci te zbirke v zvezi z znaki njene praktične glasbene uporabnosti. 